\title{
STUDI PENTANAHAN KAKI MENARA TRANSMISI 500KV SUMATERA TURUN PERANAP NEW AURDURI
}

\author{
Hari Kurniawan ${ }^{1}$, Leily.W.Johar ${ }^{2}$ \\ ${ }^{1}$ Jurusan Teknik Listrik, Fakultas Teknik, Universitas Batanghari \\ ${ }^{2}$ Dosen Teknik Listrik, Fakultas Teknik, Universitas Batanghari \\ e-mail :Kurniawan29hari@yahoo.com, leily.wustha.johar@unbari.ac.id
}

\begin{abstract}
ABSTRAK
Di dalam setiap pemasangan intalasi listrik, untuk menghindari arus yg berlebih dan gangguan akibat sambaran petir secara lansung, pentingnya pemasangan grounding (pentanahan).Terutama untuk Saluran Udara Tegangan Extra Tinggi (SUTET). Maka pemasangan harus sesuain S-PLN. Penelitian ini dilakukan untuk memporoleh informasi masalah nilai hambatan pentanahan pada kaki tower Saluran Udara Tegangan Extra Tinggi (SUTET) 500 KV Sumatera Turun Pranap Aurduri, untuk mendapatkan informasi maka dilakukan pengukuran dan perhitungan hambatan pentanahan menggunakan elektroda batang. Dari hasil perhitungan hambatan pentanahan kaki tower SUTET 500 KV Panjang elektrode $(L) 1000 \mathrm{~mm}$, Diameter elektroda $(D) 16 \mathrm{~mm}$, Jari-jari elektrode $=8 \mathrm{~mm}$, Tahanan jenis tanah $(\rho) 100 \mathrm{hm}$-meter untuk tanah liat ladang dengan hambatan jenis tanah yang berbeda menghasilkan hambatan $\pm 5 \mathrm{Ohm}$
\end{abstract}

Kata Kunci : SUTET, Pentanahan, Elektroda Batang

\section{PENDAHULUAN}

Pentanahan merupakan sistem yang umum digunakan di dunia kelistrikan yang bertujuan mengamankan peralatanperalatan listrik, maupun manusia yang berada disekitar gangguan. Untuk menyalurkan daya listrik di pusat tenaga sumber ke konsumen diperlukan suatu sistem tenaga listrik. Sistem jaringan ini terdiri dari saluran transmisi, meliputi tranmisi $500 \mathrm{kV}$, Saluran transmisi merupakan bagian yang sering mendapat gangguan, gangguan-gangguan tersebut selain gangguan dari dalam atau pada peralatan itu sendiri juga terdapat gangguan dari luar atau gangguan alam salah satunya gangguan sambaran petir terhadap saluran transmisi, karena saluran transmisi berhubungan langsung dengan lingkungan luar yang meliputi udara, air hujan, dan paparan sinar matahari yang tersebar diberbagai daerah terbuka serta beroperasi dalam segala macam kondisi. Apabila salah satu bagian sistem transmisi mengalami gangguan maka akan berdampak terhadap bagian transmisi yang lainnya.Sehingga
Saluran transmisi Gardu induk dan Saluran distribusi menjadi terganggu serta mengalami kerusakan. Transmisi dan distribusi merupakan satu kesatuan yang harus dikelola dengan baik. Mengatasi gangguan diperlukan pentanahan kaki menara transmisi yaitu perlindungan kawat fase terhadap sambaran langsung petir dengan menggunakan kawat tanah yang diletakkan di atas kawat fase, sehingga sambaran petir yang mengenai kawat tanah akan lansung di bumikan. Resistansi tanah yang tinggi menyababkan gelombang arus pantul akan merambat ke puncak menara dan apabila gelombang arus pantul tersebut melebihi tegangan isolator yang ada pada tiang transmisi, maka arus petir akan terinjeksi ke kawat fase dan mengakibatkan kerusakan. Oleh karena itu diperlukan sistem pentanahan yang baik.

\section{LANDASAN TEORI}

\subsection{SistemPentanahan}

$\begin{array}{ccc}\text { Sistem } & \begin{array}{c}\text { Pentanahan } \\ \text { Grounding })\end{array} & \text { (System } \\ \text { didefinisikan } & \text { sebagai }\end{array}$


hubungan ke tanah dari salah satu penghantar dari sistem distribusi atau sistem perkawatan di dalam mesin, Pentanahan sistem biasa dilakukan pada sekunder transformator yang mempunyai hubungan bintang.[Sumber Suhadi Dkk Teknik Distribusi Tenaga Lstrik,Penerbit Departemen Pendidikan Nasional 2008]

Hubungan bintang ialah hubungan transformator tiga fasa, dimana ujungujung awal atau akhir lilitan disatukan. Titik dimana tempat penyatuan dari ujungujung lilitan merupakan titik netral. Apabila sistem yang digunakan adalah sistem delta. .[Sumber Suhadi Dkk Teknik Distribusi Tenaga Lstrik,Penerbit Departemen Pendidikan Nasional 2008].

Hubungan segitiga adalah suatu hubungan transformator tiga fasa, dimana cara penyambungannya ialah ujung akhir lilitan fasa pertama disambung dengan ujung mula lilitan fasa kedua, akhir fasa kedua dengan ujung mula fasa ketiga dan akhir fasa ketiga dengan ujung mula fasa pertama. pentanahan dapat dilakukan dengan jalan menggunakan transformator pentanahan.[Sumber Suhadi Dkk Teknik Distribusi Tenaga Lstrik,Penerbit Departemen Pendidikan Nasional 2008].

Tujuan dari pentanahan sistem adalah sebagai berikut :[Sumber Suhadi Dkk Teknik Distribusi Tenaga Lstrik,Penerbit Departemen Pendidikan Nasional 2008]

Metoda -metoda pentanahan netral dan sistem-sistem tenaga adalah:

1. Pentanahan melalui tahanan (resistance grounding)

Adalah adalah untuk membatasi arus gangguan ke tanah antara 10- \% sampai $25 \%$ dari arus gangguan 3 fasa. Batas yang paling bawah adalah batas minimum untuk dapat bekerjanya rele gangguan tanah, sedangkan batas atas adalah untuk membatasi banyaknya panas yang hilang pada waktu terjadinya gangguan.

2. Pentanahan melalui reaktor (reactor grounding)

Reaktor pengetanahan ini digunakan bila trafo daya tidak cukup membatasi arus gangguan tanah. Pentanahan ini digunakan untuk memenuhi persyaratan dari sistem yang tanahkan dengan pentanahan ini, besarnya arus gangguan ke tanah di atas $25 \%$ dari arus gangguan 3 fasa.

\subsection{Tahanan Pentanahan}

Tahanan Pentanahan adalah salah satu faktor kunci dalam usaha pengamanan, perlindungan instalasi listrik. Agar sistem pentanahan dapat bekerja dengan efektif, sistem pentanahan harus memenuhi persyaratan sebagai berikut : [Sumber Persyaratan Umum Instalasi Listrik 2000 (PUIL 2000) Jakarta Badan Standarisasi Nasional 2000] a. Membuat jalur impedansi rendah ke tanah untuk pengamanan personil dan peralatan,menggunakan rangkaian yang efektif.

b. Dapat melawan dan menyebarkan gangguan berulang dan arus akibat sambaran pentir.

c. Bahan tahan korosi terhadap berbagai kondisi kimiawi tanah, untuk bisa dipakai dalam jangka waktu yang panjang.

d. Menggunakan sistem mekanik yang kuat namun mudah dalam pelayanan. Sistem pentanahan yang baik akan memberikan keandalan pada sistem tenaga listrik, disamping keamanan yang terjaga pada sistem tenaga listrik juga peralatan lain yang mendukungnya.

\subsection{Perlengkapan Pentanahan}

Perlengkapan Pentanahan merupakan hubungan ke tanah dari bagian-bagian metal yang dalam keadaan normal tidak membawa arus pada semua perlengkapan yang berhubungan dengan sistem tenaga listrik, seperti. Pipa-Pipa, Metal, Pelindung Kabel, Kotak saklar, Kerangka Motor, Tangki Transformator, Lemari Kontrol.

Secara singkat tujuan pentanahan peralatan dapat diformulasikan sebagai berikut : [Sumber Persyaratan Umum Instalasi 
Listrik 2000 (PUIL 2000) Jakarta Badan Standarisasi Nasional 2000]

a. Mencegah terjadinya tegangan kejut listrik yang berbahaya bagi orang yang ada dalam daerah tersebut.

b. Untuk memungkinkan timbulnya arus tertentu baik besarnya maupun lamanya dalam keadaan gangguan tanah tanpa menimbulkan kebakaran atau ledakan pada bangunan atau isinya.

c. Untuk memperbaiki performance dari sistem. Batas tahanan pentanahan perlengkapan adalah :

1) Untuk stasiun-stasiun besar, tahanan bus pentanahan $1 \mathrm{Ohm}$.

2) Untuk stasiun yang lebih kecil, tahanan bus pentanahan $5 \mathrm{Ohm}$.

3) Untuk perumahan dan kota-kota yang belum mempunyai sistem air ledeng, tahanan bus pentanah $25 \mathrm{Ohm}$.

4) Untuk peralatan-peralatan elektronis yang sangat peka, tahanan pentanahan harus kurang dari $1 \mathrm{Ohm}$, yaitu sekitar $0.5 \mathrm{Ohm}$.

5) Untuk menara transmisi $500 \mathrm{kv}$ tahanan pentanahan kaki menara tidak lebih dari $5 \mathrm{Ohm}$.

\subsection{Jenis Elektroda Pentanahan Sumber S-PLN Tahun 2014}

Rod pentanahan adalah perlengkapan pembumian sistem transmisi yang berfungsi untuk meneruskan arus listrik dari tower SUTT maupun SUTET ke tanah dan menghindari terjadinya back flashover pada insolator saat grounding sistem terkena sambaran petir. Pentanahan tower terdiri dari konduktor tembaga atau konduktor baja yang diklem pada pipa pentanahan yang ditanam di dekat pondasi tiang, atau dengan menanam plat aluminium/ tembaga disekitar pondasi tower yang berfungsi untuk mengalirkan arus dari konduktor tanah akibat sambaran petir.

Jenis-jenis pentanahan tower pada SUTT/ SUTET :

a. Electroda bar, yaitu suatu rel logam yang ditanam di dalam tanah.
Pentanahan ini paling sederhana dan efektif, dimana nilai tahanan tanah adalah rendah.

b. Electroda plat, yaitu plat logam yang ditanam di dalam tanah secara horisontal atau vertikal. Pentanahan ini umumnya untuk pengamanan terhadap petir.

c. Counter poise electrode, yaitu suatu konduktor yang digelar secara horisontal di dalam tanah. Pentanahan ini dibuat pada daerah yang nilai tahanan tanahnya tinggi atau untuk memperbaiki nilai tahanan pentanahan.

d. Mesh electrode, yaitu sejumlah konduktor yang digelar secara horisontal di tanah yang umumnya cocok untuk daerah kemiringan.

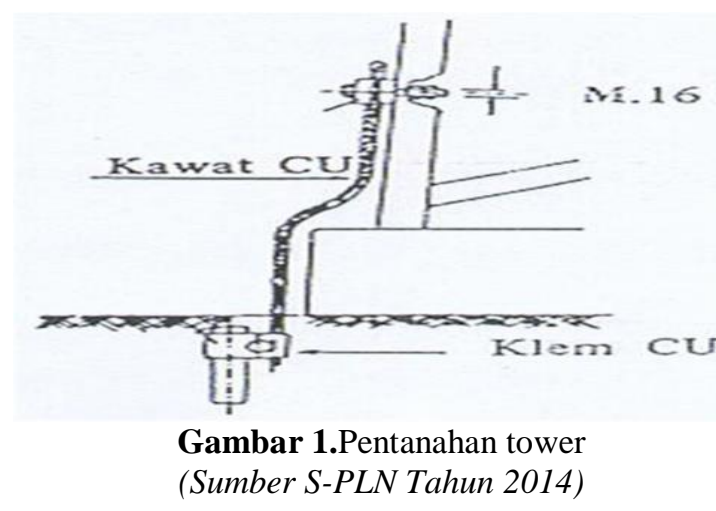

\subsection{Sifat-sifat Elektroda Pentanahan}

Sifat-sifat Elektroda Pentanahan dinilai dari tahanan tanah disekitarnya dimana secara geologis arus mengalir dari elektroda kesekitarnya. Tahanan elektroda ditentukan oleh ukuran, bentuk dan jenis elektroda yang digunakan. Tahanan kontak antara elektroda dan tanah disekitarnya diusahakan sekecil mungkin untuk menjamin tahanan pentanahan yang rendah. Namun demikian besarnya tahanan kontak sangat ditentukan jenis tanah, struktur tanah dan instalasi pemasangan elektroda. Tahanan tanah disekitar penjumlahan resistan seri dari lapisan-lapisan tanah, lapisan terdekat dengan elektroda memiliki permukaan yang sempit sehingga memberikan tahanan yang relatif besar. Lapisan berikutnya memberikan tahanan yang lebih kecil dikarenakan lebih luas, 
demikian seterusnya hingga pada suatu jarak tertentu dari elektroda. Jarak ini disebut daerah tahanan efektif, tergantung dari dalamnya elektroda.

\subsection{Tahanan Jenis Tanah}

Faktor paling dominan mempengaruhi tahanan sistem pentanahan adalah tahanan jenis tanah dimana elektroda pentanahan ditanam. Harga tahanan jenis tanah pada daerah kedalaman yang terbatas tergantung beberapa faktor, yaitu :

Tabel 1. Tahanan Jenis Tanah

\begin{tabular}{|c|c|c|c|c|}
\hline $\begin{array}{l}\text { Kelas } \\
\text { Tanah }\end{array}$ & Tipe Tanah & Kondisi Tanah & $\begin{array}{l}\text { Maksimun daya } \\
\text { dukung tanah }\end{array}$ & $\begin{array}{l}\text { Parameter }(\mathrm{C}) \text { dan sudut } \\
\text { gesek } \Phi^{\circ}\end{array}$ \\
\hline 1 & Cohesive granular & Sangat lunak tanpa pasir & $1000 \mathrm{daN} / \mathrm{m} 2$ & $\begin{array}{l}\mathrm{C}: 1500-2500 \mathrm{daN} / \mathrm{m} 2 \\
\Phi: 250-300\end{array}$ \\
\hline 2 & Cohesive granular & $\begin{array}{l}\text { Tanah lunak, endapan } \\
\text { lumpur sedikit pasir }\end{array}$ & $\begin{array}{l}2500-7500 \\
\mathrm{daN} / \mathrm{m} 2\end{array}$ & $\begin{array}{l}C: 2500-5000 \mathrm{daN} / \mathrm{m} 2 \\
\Phi: 300-350\end{array}$ \\
\hline 3 & Cohesive granular & $\begin{array}{l}\text { Tanah keras coarsif } \\
\text { berpasir gravel (tanah liat) }\end{array}$ & $\begin{array}{l}7500-1500 \\
\mathrm{daN} / \mathrm{m} 2\end{array}$ & $\begin{array}{l}\mathrm{C}: 5000-8000 \mathrm{daN} / \mathrm{m} 2 \\
\Phi: 350-400\end{array}$ \\
\hline 4 & Cohesive granular & $\begin{array}{l}\text { Lumpur sangat keras, } \\
\text { tanah liat keras berpasir }\end{array}$ & $\begin{array}{l}30.000-60.000 \\
\mathrm{daN} / \mathrm{m} 2\end{array}$ & $\begin{array}{l}C: 11000-14000 \mathrm{daN} / \mathrm{m} 2 \\
\Phi: 450-500\end{array}$ \\
\hline 5 & Rock & Batu cadas & $3.000 \mathrm{daN} / \mathrm{m} 2$ & $\begin{array}{l}\mathrm{C}: 20000-28000 \mathrm{daN} / \mathrm{m} 2 \\
\Phi: 900-1000\end{array}$ \\
\hline 6 & Cohesive granular & $\begin{array}{l}\text { Lumpur keras, endapan } \\
\text { keras }\end{array}$ & $\begin{array}{l}15.000-30.000 \\
\mathrm{daN} / \mathrm{m} 2\end{array}$ & $\begin{array}{l}C: 8000-11000 \mathrm{daN} / \mathrm{m} 2 \\
\Phi: 400-450\end{array}$ \\
\hline
\end{tabular}

Sumber : CAC Proyekkelistrikan RE-II PT PLN (persero)

Tabel 2. Tahanan Jenis Tanah

\begin{tabular}{cll}
\hline No & \multicolumn{1}{c}{ Jenis Tanah } & \multicolumn{1}{c}{ Tahanan Jenis (ohm.m) } \\
\hline 1 & Tanah rawa & 10 s.d. 40 \\
2 & Tanah liat dan & 20 s.d. 100 \\
& ladang & \\
3 & Pasir basah & 50 s.d. 200 \\
4 & Kerikil basah & 200 s.d. 3.000 \\
5 & Pasir dan & $<10.000$ \\
& kerikil kering & \\
6 & Tanah berbatu & 2.000 s.d. 3.000 \\
7 & Air laut dn & 10 s.d. 100 \\
& tawar & \\
\hline
\end{tabular}

Tahanan jenis tanah berfariasi menurut jenis tanahnya dikarenakan perbedaan konduktivitas dari masingmasing unsur penyusun tanah, Tanah dengan kelembaban tinggi akan memiliki tahanan jenis tanah yang rendah. Dengan memberi air atau membasahi tanah adalah metode konvensional untuk menurunkan tahanan jenis tanah dengan meningkatkan kelembaban tanah, Harga tahanan jenis tanah pada kedalaman yang terbatas sangat bergantung dengan keadaan cuaca. Untuk mendapatkan tahanan jenis rata-rata untuk perencanaan maka diperlukan penyelidikan atau pengukuran dalam jangka waktu tertentu. Biasanya tahanan tanah juga bergantung dari tingginya permukaan tanah dari permukaan air konstan. Metode untuk mengurangi tahanan jenis tanah akibat pengaruh musim, dilakukan dengan menanamkan elektroda pentanahan sampai mencapai kedalaman di mana terdapat air tanah yang konstan.

\subsection{Proteksi Pentanahan Kaki Menara}

Indonesia merupakan negara dengan wilayah yang mempunyai kerapatan sambaran petir cukup tinggi, Dengan demikian kemungkinan jaringan transmisi mengalami gangguan petir cukup besar. Telah banyak cara yang digunakan untuk menghindarkan atau mengurangi terputusnya aliran daya listrik akibat sambaran petir, misalnya memasang kawat tanah di atas kawat fase, memperkecil tahanan kaki menara, memasang arrester, dan sebagainya. Tahanan kaki Menara yang rendah dapat diperoleh dengan menggunakan satu atau lebih batang-batang pengetanahan (grounding rod) dan atau sistem counterpoise.

Pemilihan penggunaan batang pengetanahan dan atau sistem counterpoise 
tergantung dari tahanan jenis tanah di mana menara tersebut berada.

\subsection{Batang pentanahan}

Bila menggunakan batang pengetanahan, tahanan kaki menara dihitung dengan menggunakan persamaan sebagai berikut:

$\mathrm{R}=\frac{p}{2 \pi L}\left[\operatorname{Ln}\left(\frac{2 L}{a}\right)-1\right.$

dengan :

$\mathrm{R}=$ tahanan kaki menara (ohm)

$p \quad=$ tahanan jenis tanah (ohm)

$\mathrm{L}=$ panjang dari batang pengetanahan (meter)

$\mathrm{d}=$ diameter batang pengetanahan (meter)

Menurut persamaan di atas, tahanan kaki menara akan berkurang dengan menambah panjang pentanahan. Dalam hal ini batang pentanahan pararel digunakan, persamaan (2.3) tetap dapat digunakan untuk menghitung tahanan kaki menara ; bila variabel d diubah menjadi A dan radius batang pentanahan sama sesuai dengan persamaan (2.4). Harga A adalah kelipatan batang pentanahan yang tergantung dari penempatan masing-masing batang.

Maka penempatan yaitu :

2 batang diletakkan di mana saja

$$
\mathrm{A}=\sqrt{a r}
$$

3 batang diletakkan membentuk segitiga $\mathrm{A}=\sqrt[3]{a^{2} r}$

4 batang diletakkan membentuk persegi

$\mathrm{A}=\sqrt[4]{2 \frac{1}{2} 2^{2} a^{2} r}$

dengan :

$r=$ jari-jari masin-masing batang pengetanahan (harus sama)

$\alpha=$ jarak antara batang pengetanahan.

Tembaga dan aluminium adalah bahan yang paling sering digunakan sebagai batang pentanahan (driven ground). Namun demikian tembaga dianggap lebih tahan terhadap korosi pada daerah dengan kadar garam dan kelembaban tinggi, serta daerah dengan kondisi tanah keras.

\subsection{Counterpoise}

Untuk daerah-daerah yang mempunyai lapisan tanah yang keras dan berbatu-batu atau daerah yang tahanan jenis tanahnya tinggi, batang pentanahan tidak praktis digunakan. Counterpoise menggunakan kawat penghantar yang ditanam di dalam parit di sekitar kaki menara. Parit-parit tersebut tidak terlalu dalam, kedalamannya sekitar $30 \mathrm{~cm}$ sampai $60 \mathrm{~cm}$ dan tidak memerlukan bahan urugan khusus. Courterpoise dapat dikonfigurasikan secara radial (non kontinyu) atau secara menara ke menara (kontinyu)

a. Jenis kontinyu

Terdiri atas sebuah elektroda kawat horizontal yang ditanam di bawah saluran transmisi dari ujung ke ujung atau sepanjang bagian tertentu dan dihubungkan ke kawat pentanahan (Overhead Ground Wire) pada masingmasing tiang penyangga.

b. Jenis radial

Terdiri dari beberapa elektroda kawat horizontal dengan panjang lengan sama dan antar lengan dipisahkan dengan sudut yang sama. Berdasarkan pertimbangan karakteristik fungsi gangguan sambaran petir, penggunaan elektroda ini lebih menguntungkan.

\section{METODE PENELITIAN}

Langkah-langkah yang dilakukan dalam penelitian ini adalah dengan melakukan pengambilan data langsung dilapangan melalui pengukuranpengukuran pada objek pengetanahan, adapun flowchart dari penelitian ini ditunjukan pada gambar 6 dibawah. 


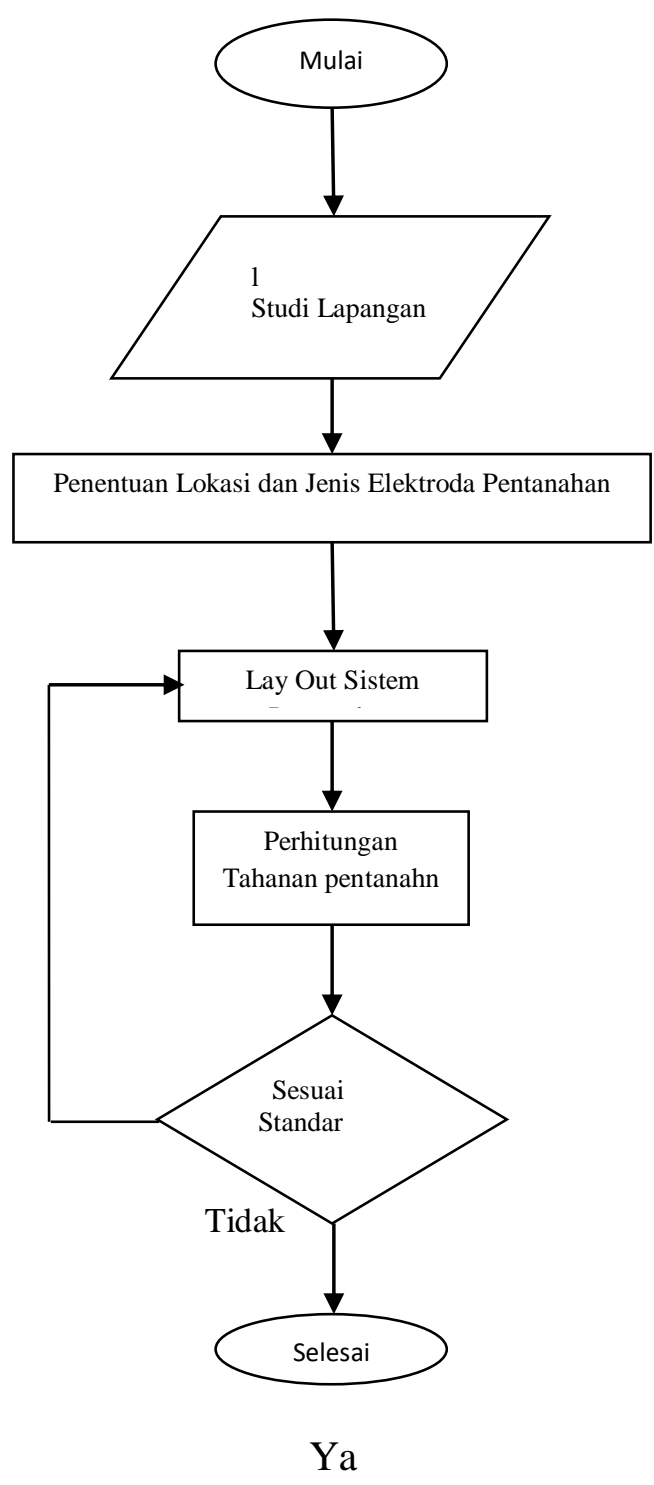

Gambar 2. Flowchart Penelitian

Dari Flow Chat dapat dijelaskan :

a. Studi Lapangan

Merupakan metode untuk mengumpulkan data secara langsung dari tempat objek penelitian, dimana pengambilan data dilaksanakan dengan cara sebagai berikut.

1) Observasi, yaitu dengan cara mengamati secara langsung untuk mendapatkan data-data primer yang lebih akurat mengenai hal-hal yang menjadi objek penelitian.

2) Menanyakan secara langsung kepada petugas dilapangan.

PT Perusahaan Listrik Negara (PLN) Mengandeng PT Waskita Karya, untuk membangun transmisi $500 \mathrm{kV}$ di Sumatra yaitu Dari Muara Enim sampai Aurduri sepanjang 554 kilometer. Hingga awal 2019 nanti, PLN menargetkan pembangunan jaringan sepanjang 19.000 kilometer sirkuit untuk seluruh wilayah sumatra, bisa mencapai total $500 \mathrm{kV}, 275 \mathrm{kV}, 150 \mathrm{kV}$, sampai $20 \mathrm{kV}$.

b. Penentuan lokasi dan Jenis Elektroda Pentanahan Elektroda pentanahan yang di gunakan pada menara transmisi $500 \mathrm{kV}$ sumatra yaitu elektroda batang yg dilapisi tembaga yang tahan dengan sehu kelembapan yang tinggi dan tahan korosi yang di tanam di sekitar menara.

c. Lay Out sistem Pentanahan

Pada proses ini di teliti lay out sistem pentanahan yang dipasang pada menara transmisi $500 \mathrm{kV}$ sumatra.

d. Perhitungan Tahanan Pentanahan Tahanan pentahanan di hitung dengan formula yang sudah di tentukan.

e. Skala Perhitungan

Di dapat harga yang sesuai standar.

f. Selesai

\section{HASIL DAN PEMBAHASAN}

\subsection{Lokasi Menara Transmisi $500 \mathrm{kV}$ Sumatra}

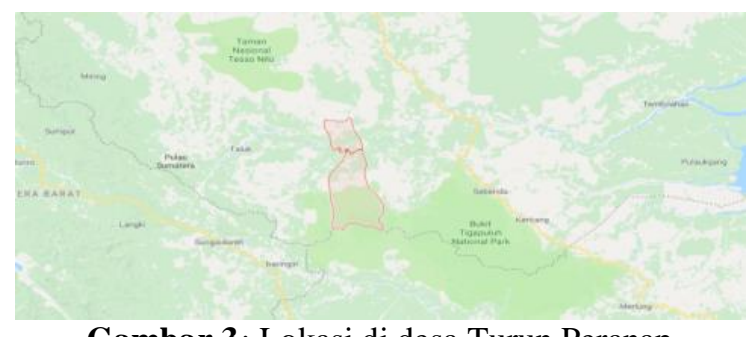

Gambar 3: Lokasi di desa Turun Peranap

\subsection{Lay Out Pentanahan}

Perlindungan saluran transmisi terhadap gangguan petir menggunakan kawat tanah, dan piranti pentanahan kaki menara untuk mengurangi resistan kaki menara. Untuk memperoleh tahanan kaki menara kurang dari $5 \mathrm{ohm}$, PT. PLN (PERSERO) menerapkan sistem pentanahan seperti terlihat pada gambar 2 . 


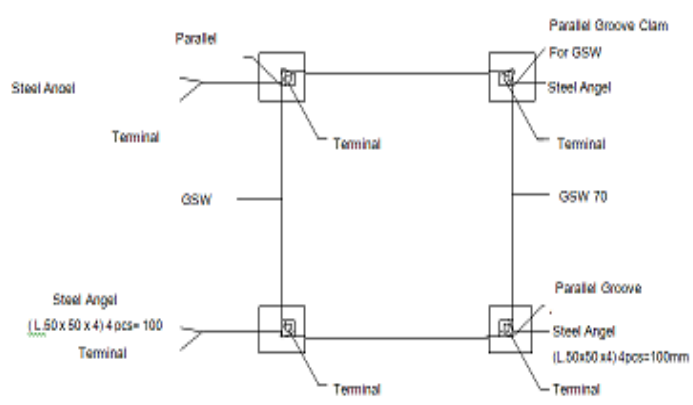

Gambar 4. Lay Out Pentanahan Kaki Menara Transmisi 500kV

Menara transmisi dipasang diatas lahan $100 \mathrm{~m}^{2}$ berbentuk bujur sangkar. Pada awal instalasi pentanahan dilakukan dengan memasang elektroda pentanaha berbentuk batang atau Rod.

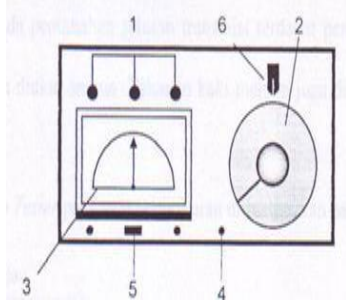

Gambar 5. Earth Tester

Keterangan :

1. Terminal.

2. Skala Pembacaan.

3. Indikator.

4. Tombol.

5. Saklar Untuk Pemilihan Pengukuran.

6. Indeks Pada Skala.

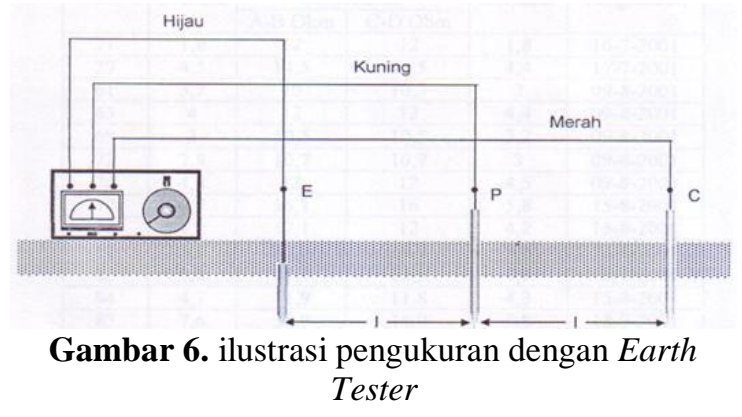

Pengukuran dilakukan dengan cara sebagai berikut:

1. Semua terminal kabel dipasang pada alat ukur.

2. Mengecek tegangan baterai earth tester dengan cara saklar diarahkan ke kiri,
Tahanan kaki harus bernilai rendah, karna seiring berjalan waktu terjadi perubahan struktur tanah, perubahan kelembaban dan perubahan tingkat kandungan air mengakibatkan tingginya resistivitas tanah. Kondisi ini akan semakin buruk ketika musim kemarau panjang.

\subsection{Pengukuran Tahanan Pentanahan Kaki Menara}

PT.PLN (Persero) menggunakan Earth Tester untuk mengukur tahanan pentanahan. Gambar 4.4 adalah alat ukur Earth tester. Hal ini dilakukan untuk memantau kondisi fisik berikut sistem pentanhannya.

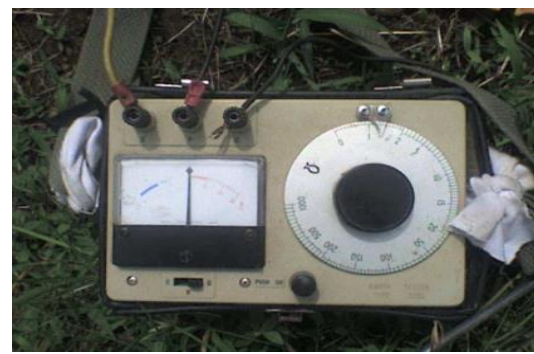

pada skala pembacaan apabila jarum mengarah ke kiri menjauh maka bertanda isi baterai penuh, dan arah kekanan semakin mendekati 0 artinya baterai kosong (tidak bisa digunakan).

3. Baut sambungan pada penghantar pentanahan dan elektroda pentanahannya dilepas, karat yang menenmpel dibersihkan.

4. Terminal dengan kabel hijau dihubungkan pada bagian yang akan diukur, probe kabel kunimg ditancapkan pada tanah dengan jarak 5-10 meter dengan probe kabel merah.

5. Tombol (NO. 4) ditekan, jarum akan bergerak kemudian jarum diatur tepat pada posisi nol. Tombol dilepas maka jarum akan bergerak menunjukkan besar tahanan yang diukur.

Analisa kondisi tahanan tower Transmisi $500 \mathrm{kV}$ Turun Peranap terbagi dalam 3 macam batasan yaitu : 
1. Tahanan pentanahan keseluruhan (gabungan)

Pengukuran tahanan pentanahan dimana arde belum dilepas dari kaki tower, dengan kata lain masih dalam keadaan utuh.

2. Tahanan pentanahan kaki tower (tanpa pentanahan)

Pengukuran tahanan pentanahan dimana arde dilepas dari kaki tower, sehingga hanya tahanan dari kaki tower saja yang di ukur.

3. Tahanan pentanahan arde kaki tower (menara tidak terhubung).

Pengukuran tahanan pentanahan dimana arde sudah dilepas kemudian arde diukur.

\subsection{Perhitungan Pentanahan}

Sebelum dilakukan instalasi elektroda batang, harus terlebih dahulu ditentukan desain dari elektoda batang, lalu dihitung nilai tahanan elektroda batang sesuai standart yaitu harus dibawah $5 \Omega$ (ohm) untuk elektroda batang tunggal. Adapun perkiraan desain dan perhitungan nilai tahanan adalah sebagai berikut:

$\begin{array}{ll}\text { Panjang elektrode }(L) & =1000 \mathrm{~mm} \\ \text { Diameter elektroda }(D) & =16 \mathrm{~mm} \\ \text { Jari-jari elektrode }(\Pi) & =8 \mathrm{~mm} \\ \text { Tahanan jenis tanah }(\rho) & =1000 \mathrm{Om}-\end{array}$
meter

untuk tanah liat ladang

$$
\mathrm{R}_{\mathrm{A}}=\frac{p}{2 \Pi L}\left[\operatorname{Ln}\left(\frac{2 L}{a}\right)-1\right]
$$

Dimana :

$\rho=$ Tahanan jenis tanah (ohm meter)

$L=$ Panjang elektroda batang (meter)

$a=$ Jari-jari penampang elektroda (meter)

$R=$ Tahanan elektroda ke tanah (ohm)

$$
\begin{aligned}
\mathrm{R}_{\mathrm{A} 1} & =\frac{p}{2 \pi L}\left[\operatorname{Ln}\left(\frac{2 L}{a}\right)-1\right] \\
& =\frac{100}{2.3,14.1}\left[\operatorname{Ln}\left(\frac{2 x 1}{0,008}\right)-1\right] \\
& =72 \Omega
\end{aligned}
$$

Nilai perhitungan tahanan pentanahan untuk satu buah batang elektrode yang ditanam tegak lurus kedalam tanah adalah 72 Ohm. Jadi perhitungan nilai tahanan pentanahan elekrode batang tunggal telah memenuhi persyaratan yang berlaku yaitu dibawah 5 Ohm. Hasil penelitian menunjukan bahwa konfigurasi penanaman elektroda batang mampu menginduksi besarnya tahanan pentanahan, artinya semakin banyak elekroda ditanam dalam tanah,maka semakin kecil nilai tahannan pentanahannya.

Parameter yang ditekankan adalah tahanan pentanahan karena parameter ini sangat menentukan perlindungan pada saluran transmisi. pada titik terdekat menara tersebut, Parameter ini akan menjamin saluran yang memadai bagi arus sambaran petir untuk diredam oleh tanah, melalui menara. Nilai tahanan kaki menara dipengaruhi oleh tahanan gabungan kaki menara dan tahanan pentanahan menara sistem transmisi karena terhubung oleh kawat tanah, begitu juga parameter tahanan bersama yaitu tahanan sistem yang diukur setelah kaki menara dan piranti pentanahan dihubungkan. Parameter tahanan pentanahan sangat menentukan kualitas sistem pentanahan kaki menara, karena tidak akan mungkin diperoleh tahanan menara dan tahanan bersama yang rendah ketika seluruh tahanan pentanahan bernilai tinggi. Arus petir akan langsung mengalir ke tanah melalui menara tersebut.

Untuk setiap kaki menara di pasang 4 elektroda pentahan yang di hubungkan paralel. Maka tahanan pentanahan untuk satu kaki menara dapat di hitung:

$\frac{1}{\mathrm{R}_{\mathrm{A}}}=\frac{1}{\mathrm{R}_{\mathrm{A} 1}}+\frac{1}{\mathrm{R}_{\mathrm{A} 2}}+\frac{1}{\mathrm{R}_{\mathrm{A} 3}}+\frac{1}{\mathrm{R}_{\mathrm{A} 4}}$

Dimana : $R_{A 1}=R_{A 2}=R_{A 3}=R_{A 4}$

$\frac{1}{\mathrm{R}_{\mathrm{A}}}=\frac{1}{72}+\frac{1}{72}+\frac{1}{72}+\frac{1}{72}$

$\frac{1}{\mathrm{R}_{\mathrm{A}}}=\frac{4}{72}$

Maka : 


$$
\mathrm{R}_{\mathrm{A}}=\frac{72}{4}=18 \Omega
$$

Pada kondisi ini, tiap kaki menara mempunyai tahanan yang sama yaitu:

$R_{A 1}=R_{A 2}=R_{A 3}=R_{A 4}$

Hasil perhitungan tahanan pentanahan tiap kaki menara dapat di lihat pada tabel 4.1 berikut :

Tabel 3. Tahanan Pentanahan Tiap Kaki Menara

\begin{tabular}{|c|c|c|c|c|c|}
\hline \multirow{3}{*}{ No } & \multirow{3}{*}{$\begin{array}{l}\text { Kaki } \\
\text { Tower }\end{array}$} & \multicolumn{2}{|r|}{ Pentanahan } & \multicolumn{2}{|l|}{$\Omega$} \\
\hline & & A & B & $\mathrm{C}$ & $\mathrm{D}$ \\
\hline & & $\Omega$ & $\Omega$ & $\Omega$ & $\Omega$ \\
\hline 1 & 1 & 72 & 72 & 72 & 72 \\
\hline 2 & 2 & 72 & 72 & 72 & 72 \\
\hline 3 & 3 & 72 & 72 & 72 & 72 \\
\hline 4 & 4 & 72 & 72 & 72 & 72 \\
\hline
\end{tabular}

Dari perhitungan di atas, di dapatkan hasil perhitungan pentanahan tiap kaki menara dengan nilai $18 \quad \Omega$ yang dihubungkan secara paralel.

Secara keseluruhan sistem pentanahan pada menara transmisi ini adalah. 4,5 $\Omega$ dimana setiap kaki menara dipasang 4 elektroda pentanahan yang dihubungkan paralel. dihitung:

Maka dari hasil di atas dapat $R_{A}=R_{B}=R_{C}=R_{D}$

$\frac{1}{R_{\text {total }}}=\frac{1}{\mathrm{R}_{\mathrm{A}}}+\frac{1}{\mathrm{R}_{\mathrm{B}}}+\frac{1}{\mathrm{R}_{\mathrm{C}}}+\frac{1}{\mathrm{R}_{\mathrm{D}}}$

$\frac{1}{R_{\text {total }}}=\frac{1}{18}+\frac{1}{18}+\frac{1}{18}+\frac{1}{18}=\frac{4}{18}$

Maka :

$R_{\text {total }}=\frac{18}{4}=4.5 \Omega$

Secara perhitungan jadi nilai tahanan pentanahan pada menara Transmisi $500 \mathrm{KV}$ Turun Peranap New - Aurduri adalah 4,5 $\Omega$.

\section{SIMPULAN}

Dari hasil pengukuran kondisi tahanan pentanahan transmisi di dapati hasil pentanahan $4,5 \Omega$

a. Konfigurasi penanaman elektroda batang mampu mereduksi besarnya tahanan pentanahan.

b. Hasil pentanahan sesuai dengan S-PLN yaitu kurang dari $5 \Omega$

\section{DAFTAR PUSTAKA}

[1] Iskan, Dahlan, Kriteria Desain Engineering Konstruksi Jaringan Distribusi Tenaga Listrik, PT. PLN (PERSERO), Jakarta, 2010.

[2] Panjaitan, Bonar, Praktik-Praktik Proteksi Sistem Tenaga Listrik, Penerbit andi Yogyakarta,2012.

[3] Persyaratan Umum Instalasi Listrik 2000 (PUIL 2000). Jakarta : Badan Standarisasi Nasional,2000.

[4] PLN, Buku I Kriteria desain Enjinering Konstruksi Jaringan Distribusi Tenaga Listrik, Penerbit PT-PLN, 2010.

[5] Setiawan, P.Van Harten, Ir.e, Instalasi Listrik Arus Kuat II, Cv. Trimitra Mandiri.

[6] Suhadi Dkk, Teknik Distribusi Tenaga Lstrik,Penerbit Departemen Pendidikan Nasional,2008. 